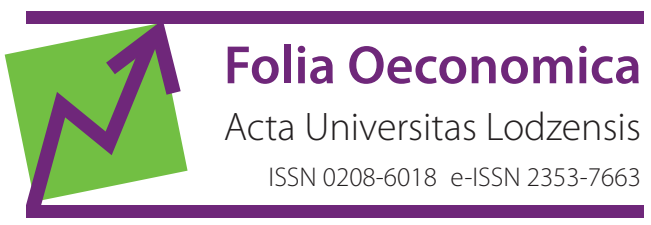

www.czasopisma.uni.lodz.pl/foe/

1 (327) 2017

DOI: http://dx.doi.org/10.18778/0208-6018.327.08

\title{
Karol Flisikowski
}

Politechnika Gdańska, Wydział Zarządzania i Ekonomii, Katedra Nauk Ekonomicznych,

karflisi@pg.gda.pl

\section{Przestrzenne podejście do analizy międzysektorowej mobilności płac oraz zatrudnienia}

Streszczenie: Głównym celem opracowania jest przedstawienie możliwości zastosowania macierzy sąsiedztwa, opartej na odległości ekonomicznej, w prowadzonych przez autora analizach wiążących międzysektorową mobilność płac oraz zatrudnienia. Obliczenia odległości ekonomicznej oparto na poziomie PKB, natomiast w modelu przestrzennym wykorzystano dane dotyczące ich wybranych determinant, np. wskaźnika nierówności płacowych, przeciętnego poziomu płac, stopy bezrobocia, miernika instytucjonalizmu. Przekrój czasowy analizy uzyskano dzięki zastosowaniu mierników mobilności bazujących na macierzy prawdopodobieństw przejść oszacowanych z użyciem procesów Markowa dla danych zagregowanych. Z uwagi na dostępność jednorodnych, wysoce zagregowanych (do poziomu sektora) danych jedynie dla lat 1994-2010 ograniczono się do przeprowadzenia analizy wyłącznie dla 19 wybranych krajów OECD.

Słowa kluczowe: mobilność międzysektorowa, mobilność płacowa, mobilność zatrudnienia, nierówności płacowe.

JEL: J21, J62 


\section{Wprowadzenie}

Mobilność płac i zatrudnienia jest zagadnieniem niezwykle szeroko rozumianym i analizowanym. W niniejszym opracowaniu mobilność ta jest rozważana jako zmiana struktury sektorowych płac i zasobów pracy (zatrudnienia) w czasie. Ruchliwość strukturalna może być charakteryzowana za pomocą wielu stosowanych w jej analizach wskaźników. To od nich zależy docelowa interpretacja i sens ekonomiczny. Może ona być związana z różnymi czynnikami swojego otoczenia ekonomicznego. Należą do nich między innymi: kapitał ludzki specyficzny dla sektora (nierzadko utożsamiany z sektorowymi płacami), poziom bezrobocia, instytucjonalizmu, nierówności płacowe czy też dochodowe. Szereg badań literaturowych z tego zakresu potwierdza istnienie wyraźnych związków obu ruchliwości (nie tylko na poziomie sektora) z wyżej wymienionymi czynnikami, przez co, zdaniem autora, istnieją przesłanki ku temu, by sądzić, iż również pośrednio obie mobilności międzysektorowe - płac oraz zatrudnienia - mogą być ze sobą związane.

Głównym celem niniejszego opracowania jest próba syntetycznego ujęcia związku obu mobilności wraz z jej głównymi determinantami w formie jednego, przestrzennego modelu regresji. Wyboru modelu przestrzennego dokonano ze względu na możliwość wykorzystania dzięki niemu dodatkowej interpretowalności uzyskanych wyników, wdrażając macierz wag (sąsiedztwa) opartą na dystansach ekonomicznych. Dodatkowym atutem badań empirycznych przedstawionych w tym artykule jest także sama forma mobilności międzysektorowej. Autor zdecydował się na zastosowanie najbardziej zagregowanych danych - na poziomie sektora gospodarki - oraz na analizę przesunięć płac oraz poziomów zatrudnienia, mierzoną przy wykorzystaniu procesów Markowa.

\section{Międzysektorowa mobilność płac oraz zatrudnienia}

Mobilność międzysektorowa (MMS) może być rozumiana jako międzysektorowy przepływ siły roboczej (Lilien, 1982; Wacziarg, Wallack, 2004) - międzysektorowa mobilność zatrudnienia (MMZ). MMS może oznaczać także stopień międzysektorowego zróżnicowania płac (międzysektorowa mobilność płac - MMP). W większości opracowań (zarówno teoretycznych, jak i empirycznych dotyczących obu typów mobilności) natrafić można na bardzo podobne próby wyjaśnienia determinant kształtujących poziom mobilności. Skłania to do stwierdzenia, iż w badaniach nad relacją między obiema mobilnościami istnieją trudności w ustaleniu przyczyny i skutku, natura drugiej z nich ma bowiem charakter endogeniczny, a więc istnieje przypuszczenie, iż hipotetyczna relacja jest tzw. sprzężeniem zwrotnym.

Relacja mobilności zatrudnienia do poziomu samej płacy to bardzo popularny przedmiot wielu badań w literaturze, natomiast niezwykle rzadko spotkać 
można jej odniesienie do skali mobilności płacowej. Pod tytułami publikacji tego typu kryje się bowiem przeważnie porównanie mobilności zasobowej do dynamiki bądź wzrostu poziomu płac. W zdecydowanej większości badań nad zależnością między mobilnością zatrudnienia a wzrostem płac znaleźć można wspólne wnioski. Przykładami takich analiz są prace, które prowadzili m.in.: K. Keith i A. McWilliams (1997; 1999), A. Bartel i G. Borjas (1981), J. Mincer (1986), R.H. Topel i M.P. Ward (1992), P.J. Loprest (1992), J.J. Antel (1983; 1986). Udowodniono tu, iż mobilność zasobowa prowadzi do wzrostu poziomu płac (zazwyczaj od 10 do 20\%). Wyjątki stanowią prace J.J. Antela (1983), M.J. Moore'a i in. (1998) oraz K.J. McLaughlina (1990). Istnieje wiele podejść teoretycznych, które wiążą ze sobą mobilność płacową i mobilność zatrudnienia. Jednym z pierwszych takich podejść jest model mover-stayer prezentowany przez I.M. Blumena $\mathrm{i}$ in. (1955), z psychologicznymi argumentami, jakoby pracownicy byli z natury mobilni, a sam proces skorelowany był z brakiem miejsca (pracy), by pozostawać na jednym stanowisku i w innych sferach życia. Bardziej niestabilne jednostki byłyby więc mniej produktywne i otrzymywałyby niższe płace od innych. Inne modele uwzględniające połączenie między mobilnościami płac i zasobów zostały sklasyfikowane jako statyczne bądź dynamiczne (Naticchioni, Panigo, 2004) ze względu na odrzucenie założenia o dynamizmie płac w zakresie stanowisk. Podejście teorii poszukiwań mogłoby więc zostać sklasyfikowane jako statyczne, natomiast np. nurt specyficznego kapitału ludzkiego oraz selekcji jako dynamiczny. Modele statyczne pozwalają na ujęcie zależności dynamiki płac jako zmian w zakresie stanowiska, sektora itp., natomiast dynamiczne pozwalają również ująć zmiany płac w połączeniu z przesunięciami zasobów pomiędzy i w zakresie stanowisk, sektorów. W modelach poszukiwań wskazuje się najczęściej na to, iż krótszy staż skorelowany jest ze wzrostem poziomu mobilności płacowej oraz z tym, iż przynosi ona największe „zyski” płacowe na początku kariery zawodowej. Te same wnioski określone są przez tę teorię w wersji, która przedstawił B. Jovanovic (1979) czy też K. Burdett (1978).

W teorii kapitału ludzkiego (Becker, 1962; Light, McGarry, 1998) wskazuje się na odwrotną zależność między mobilnością zasobową a inwestowaniem w specyficzne umiejętności pracy, lecz nie określa się jasno i precyzyjnie związku między mobilnością zatrudnienia a ruchliwością płac. Mowa tu jedynie o tym, iż im więcej specyficznego kapitału ludzkiego się transferuje, tym niższy będzie oczekiwany spadek płac w związku ze spodziewaną mobilnością zatrudnienia. Innym dynamicznym podejściem do badań nad związkiem obu mobilności jest teoria poszukiwań, w której pracownik poszukuje oferty pracy w celu znalezienia najlepszego dopasowania do swoich oczekiwań. B. Jovanovic (1979) uważał, iż im gorsza jakość takiego dopasowania, tym krótszy jest również okres zatrudnienia pracownika na takim stanowisku. Płace wzrastają tu poprzez pracę jako nagrodę za poszukiwanie lepszego dopasowania, niezależnie od akumulacji specyficznego kapitału 
ludzkiego. Teoria dopasowań (ang. job-match theory) nie rozstrzyga jednak bezpośrednio o dokładnym związku obu mobilności (Naticchioni, Panigo, 2004).

Wymienione wcześniej teorie biorą pod uwagę wyłącznie indywidualne wybory lub też nieobserwowalne charakterystyki, lecz żadna z nich nie uwzględnia roli otoczenia instytucjonalnego. Większość modeli przeznaczona jest specjalnie (wręcz dopasowana) do instytucjonalnego charakteru rynku amerykańskiego, podczas gdy europejskie rynki pracy przedstawiają pod tym względem inną specyfikę (warunkuje ona zarówno mobilność zatrudnienia, jak i kształtowanie się płac). P. Naticchioni i D. Panigo (2004) przedstawiają możliwość zwiększenia kosztów zwolnień, co jest istotnym elementem polityki ochrony zatrudnienia w całej Europie. Skonstruowali oni model teoretyczny, w którym optymalne warunki zmiany pracy determinują pozytywną korelację między długością zatrudnienia a krótkookresowymi wzrostami skali mobilności. Czynniki instytucjonalne mogą wpływać zarówno na przesunięcia w strukturze zatrudnienia, jak i w dynamice płac - na wiele sposobów. W pierwszym przypadku prawna ochrona zatrudnienia ma znaczącą rolę w zwalnianiu pracowników oraz zatrudnianiu nowych na okres tymczasowy. Im bardziej elastyczny rynek pracy, tym większe są spodziewane tego efekty - mobilność może mieć erozyjny wpływ na płace. W krajach z wyższym stopniem zabezpieczeń zatrudnienia wszelkie zmiany mogą być bardziej zyskowne ze względu na to, iż dokonują się zwykle w przypadku dostrzeżenia oferty pracy z wyższym wynagrodzeniem. Drugim istotnym czynnikiem instytucjonalnym jest kompensacja bezrobocia i hojność w środkach zapewniających znalezienie nowego zatrudnienia. Kraje bardziej liberalne pod tym względem mogą oczekiwać dłuższych okresów bezrobocia, powiększając tym samym lukę płacową osób tracących pracę, choć efekt ten nie jest tak wyraźny dla osób dobrowolnie zmieniających pracę. Na proces kształtowania płac wpływ mają także: stopień uzwiązkowienia, centralizacja, układy zbiorowe. Kraje o niskim natężeniu związkowości i słabym stopniu negocjacji zbiorowych powinny rejestrować wyższą dynamikę płac realnych. Wreszcie, im bardziej zdecentralizowane są układy zbiorowe, tym oczekuje się wyższych potencjalnych zwyżek lub spadków płac w przypadku zmian pracy.

Jeśli chodzi natomiast o związki mobilności z szeroko rozumianym instytucjonalizmem oraz nierównościami, należy stwierdzić, iż większość analiz prowadzonych w tym zakresie bazuje na twierdzeniu M. Friedmana (1962), iż wśród dwóch społeczeństw z jednakowymi rozkładami dochodów, to właśnie kraj z wyższym poziomem mobilności jest bardziej egalitarny. Friedman wskazuje też na to, iż wyższa mobilność płacowa jest oznaką bardziej dynamicznej, elastycznej i wydajnej gospodarki. Instytucje rynku pracy odpowiedzialne są natomiast za różnice w mobilności płacowej i samych nierównościach płacowych. Wśród instytucji z tej grupy rozróżnić można takie, które bezpośrednio wpływają na pracodawców i ich zdolność do dostosowywania płac swoich pracowników. Takie instytucje to np. płaca minimalna czy też związki zawodowe, których działanie może być mierzone przez poziom uzwiązkowienia, a także 
zakres negocjacji zbiorowych. Poza tym inne instytucje mogą wpływać na mobilność płac pośrednio - przez mobilność zatrudnienia. Elastyczność we wprowadzaniu na rynek pracy tymczasowych kontraktów, tak jak użycie tymczasowej siły roboczej, jej zatrudnianie i zwalnianie, związana jest ściśle ze zagregowanym poziomem mobilności zasobów pracy.

Mobilność międzysektorowa i jej zależność od krótkookresowych, zagregowanych fluktuacji zmiennych ekonomicznych to niezwykle istotny wątek w literaturze (Abraham, Katz, 1986; Murphy, Topel, 1987; Loungani, Rogerson, 1989; Altonji, Ham, 1990; Palley, 1992; Brainard, Cutler, 1993; Chan, 1996; Garonna, $2000 \mathrm{i}$ inni). Badania te dowodzą, iż istnieje pozytywna zależność między mobilnością siły roboczej na poziomie sektorowym a zagregowaną stopą bezrobocia. Łączenie tych dwóch trendów jest nadal przedmiotem dyskusji i wielu kontrowersji. W badaniach wykorzystujących dane dotyczące tzw. worker turnover (dopływy pracowników z bezrobocia oraz wcześniej niepracujących) wykazano pozytywną korelację (Aghion, Blanchard, 1994), w kolejnych negatywną (Krugman, 1994), a w jeszcze innych kompletny jej brak. Natomiast w badaniach wykorzystujących przesunięcia w strukturze sektorowej (np. Basile, 2010; Mussida, Pastore, 2012; 2014) określono kierunek związku jako dodatni.

\section{Pomiar mobilności międzysektorowej}

Mobilność płacowa i zasobowa w większości przeprowadzonych badań empirycznych napotkanych $\mathrm{w}$ literaturze mierzona była z użyciem indywidualnych mikrodanych. Pociągało to za sobą konsekwencje w stosowaniu specyficznych metod statystycznych. Stąd w przeważającej części badań napotkać można te same rozwiązania metodologiczne. Zmiany zatrudnienia mogą być także obserwowalne dzięki zastosowaniu macierzy przejść przez analizę łańcuchów Markova. Pierwsze tego typu prace przeprowadził E. Funkhouser (1996; 1997) i W.F. Maloney (1999). M. Bosch i W.F. Maloney (2010) stwierdzili, iż mobilność zatrudnienia może być postrzegana jako proces, $\mathrm{w}$ którym zmiany $\mathrm{w}$ wielkości poszczególnych stanów są losowe w czasie, a prawdopodobieństwa tych zmian są zarządzane przez macierze przejść Markova. E. Fabrizi i C. Mussida (2009) podkreślają, iż modele Markova umożliwiają estymację macierzy przejść, kiedy obiekty badania są nie tylko w dyskretnych punktach czasu, a dokładne daty przejść nie są znane - stąd są one bardzo uniwersalnym narzędziem. Mogą być więc stosowane nie tylko w przypadku indywidualnych danych, ale także w przypadku znacznego stopnia agregacji. Badania tego typu przeprowadzili także m.in.: A. Bigsten i in. (2007), G.J. Canavire-Bacarreza i L.F. Soria (2007), G. Krstic i P. Sanfey (2007), A. Tansel i E.O. Kan (2012). Poza estymacją macierzy przejść między poszczególnymi stanami (elementami rynku pracy, jakimi są np. sektory) analiza tego typu umoż- 
liwia, podobnie jak w przypadku konstrukcji kwantylowych macierzy przejścia, zmierzenie wielkości mobilności w postaci syntetycznego wskaźnika (opartego na śladzie macierzy bądź np. jej wyznaczniku).

$\mathrm{W}$ pracy stosowane jest najmniej popularne rozwiązanie - zagregowane do poziomu sektorów dane oraz estymacja z użyciem modelu prawdopodobieństwa Markowa (Markov, 1906). Model prawdopodobieństw przejść Markowa bazuje na zestawie dyskretnych stanów (np. sektorów), w których można sklasyfikować wszystkie obserwacje (np. firmy, instytucje, pracowników). Niech $R$ oznacza dyskretne kategorie, w których uporządkowano wszystkie obserwacje. Macierz przejść $P=\left[p_{i j}\right]$ można zdefiniować jako macierz obrazującą prawdopodobieństwa, iż poziom płacy w danym stanie - sektorze (lub zatrudnienie) nie zmieni się bądź zmieni się i przepłynie do sektora $R-1 \mathrm{w}$ danym horyzoncie czasowym. Każdy element macierzy, $p_{i j}$, przedstawia prawdopodobieństwo, iż poziom płacy/zatrudnienia jest równy $i$ w okresie $t-1$ oraz poziom płacy/zatrudnienia jest równy $j$ w okresie $t(1)$.

$$
P=\left[\begin{array}{cccc}
p_{1} & p_{2} & \cdots & p_{1 R} \\
p_{2} & p_{2} & \cdots & p_{2 R} \\
\vdots & \vdots & \ddots & \vdots \\
p_{R 1} & p_{R 2} & \cdots & p_{R}
\end{array}\right]
$$

W analizie wykorzystano prostą strukturę prawdopodobieństw przejść Markowa, z uwzględnieniem stacjonarnych procesów Markowa pierwszego rzędu' ${ }^{1}$ Przy tym założeniu jedyną istotną informacją objaśniającą zachowanie się szeregu struktur płacowych i zasobowych jest ich układ w poprzednim okresie. Przy założeniu stacjonarności całego procesu można przedstawić prawdopodobieństwa przejścia $p_{i j}$ W formie macierzy prawdopodobieństw przejścia (o wymiarach $\mathrm{R} \times \mathrm{R}$ ), w której $P=\left[p_{i j}\right]$. Macierz ta posiada własność sumowania się wierszy do jedności.

\subsection{Estymacja macierzy przejść dla danych zagregowanych}

Szacowanie macierzy przejść z wykorzystaniem serii danych indywidualnych jest procesem niezwykle prostym. W tym wypadku oszacowanie prawdopodobieństwa

${ }^{1}$ Założenie procesu Markowa pierwszego rzędu może poniekąd zakłócać istniejące w rzeczywistości wolne tempo reakcji na otoczenie ekonomiczne zmian w strukturze płac czy też zatrudnienia. W tym wypadku należałoby skorzystać z nieco dłuższego okresu analizy oraz zastosować proces Markowa wyższego rzędu. Jednakże spowodowałoby to znaczący wzrost poziomu skomplikowania modelu, a więc pojawiłyby się techniczne problemy w estymacji oraz wzrosłyby gwałtownie wymagania dotyczące okresu analizy. 
jednostki będącej w stanie $j$ w okresie $t$, gdy w okresie $t-1$ znajdowała się w stanie $i$, oznaczone przez pij, sprowadza się do następującej postaci estymatora (2):

$$
p_{i j}=\frac{n_{j}}{\sum_{j} n_{j}} .
$$

Prawdopodobieństwo przejścia $\mathrm{z}$ dowolnego stanu $i$ jest równe proporcji tych jednostek, które na początku znajdowały się w stanie $i$ oraz na końcu w stanie $j$ jako proporcja wszystkich jednostek, które na początku można było obserwować w stanie $i$. Używając metody opisanej powyżej, możliwe jest oszacowanie całej macierzy przejścia z wykorzystaniem danych ilościowych. T.W. Anderson i L.A. Goodman (1957) wykazali, iż estymator (2) jest obciążonym estymatorem największej wiarygodności, a obciążenie to spada do zera wraz ze wzrostem liczebności próby. W przypadku danych o wysokim stopniu agregacji nie jest niestety możliwe zastosowanie estymatora największej wiarygodności, używając równania (2). Jednakże, jeśli szereg czasowy struktur danych jest wystarczająco długi, możliwe jest oszacowanie macierzy przejść z użyciem danych zagregowanych, wykorzystując metody programowania kwadratowego. Należy wówczas założyć, iż - zamiast obserwacji indywidualnych przejść - obserwować będziemy jedynie zagregowane proporcje $y_{j}(t)$ oraz $y_{j}(t-1)$, które reprezentują proporcje obserwacji z sektorów $j$ oraz $i \mathrm{w}$ dwóch kolejnych okresach. Zapisać można w takim przypadku stochastyczną zależność (3) ukazującą bieżące zachowanie się $y_{j}(t)$ :

$$
y_{j}(t)=\sum_{i} y_{i}(t-1) p_{j}+u_{j}(t-1)
$$

gdzie: $y_{j}(t)$ to bieżąca obserwacja, $p_{i j}$ to nieznane elementy macierzy prawdopodobieństw przejścia, natomiast $u_{j}(t)$ to odchylenia (błędy), które powinny być minimalizowane.

Zgodnie z niezwykle istotnymi badaniami nad techniką estymacji Markowskich macierzy przejść dla zagregowanych danych przeprowadzonymi przez T.C. Lee, G.G. Judge’a i A. Zellnera (1970), można zapisać to równanie w wersji macierzowej (4):

$$
y=X p+u,
$$

gdzie:

$$
\begin{aligned}
& y=\left[\begin{array}{llll}
y_{1} & y_{2} & \ldots & y_{R-1}
\end{array}\right]^{\prime}= \\
& =\left[\begin{array}{llllll}
y_{1}(1) & y_{1}(2) \ldots, y_{1}(T) & y_{2}(1) & y_{2}(2) \ldots, y_{2}(T) & \ldots & y_{R-1}(1) y_{R-1}(2) \ldots, y_{R-1}(T)
\end{array}\right]^{\prime}
\end{aligned}
$$




$$
\begin{aligned}
& X_{j}=\left[\begin{array}{cccc}
y_{1}(0) & y_{2}(0) & \cdots & y_{R}(0) \\
y_{1}(1) & y_{2}(1) & \cdots & y_{R}(1) \\
\vdots & \vdots & \ddots & \vdots \\
y_{1}(T-1) & y_{2}(T-1) & \cdots & y_{R}(T-1)
\end{array}\right] \text { dla } j=1,2, \ldots, R-1 \\
& X=\left[\begin{array}{cccc}
X_{1} & 0 & \cdots & 0 \\
0 & X_{2} & \cdots & 0 \\
\vdots & \vdots & \ddots & \vdots \\
0 & 0 & \cdots & X_{R-1}
\end{array}\right] \\
& p=\left[\begin{array}{llll}
p_{1} & p_{2} & \cdots & p_{R=1}
\end{array}\right]^{\prime} \\
& =\left[p_{1}, p_{2}, \ldots, p_{R 1} \quad p_{2}, p_{2}, \ldots, p_{R 2} \quad \cdots \quad p_{1, R-1}, p_{2, R-1}, \ldots, p_{R, R-1}\right] \\
& u=\left[\begin{array}{llll}
u_{1} & u_{2} & \ldots & u_{R-1}
\end{array}\right]^{\prime}= \\
& =\left[u_{1}(1) u_{1}(2) \ldots, u_{1}(T) \quad u_{2}(1) u_{2}(2) \ldots, u_{2}(T) \quad \ldots \quad u_{R-1}(1) u_{R-1}(2) \ldots, u_{R-1}(T)\right]^{\prime}
\end{aligned}
$$

Lee, Judge i Zellner (1970: rozdziały 1 i 3) sugerują zminimalizowanie sumy kwadratów błędów w równaniu (4) przez zastosowanie metody najmniejszych kwadratów z wyłączeniem ograniczeń liniowych prawdopodobieństw przejścia p. Metoda najmniejszych kwadratów jest według tych autorów równoważna rozwiązaniu problemu programowania kwadratowego (10):

$$
{ }_{p} u^{\prime} u=(y-X p)^{\prime}(y-X p) \rightarrow \min .
$$

Mając na uwadze: $\sum_{j=1}^{R-1} p_{i j} \leq 1 \mathrm{i} \sum_{j=1}^{R-1} p_{R_{j}}=0$, a także $p_{i j} \geq 0$, równanie (10) zapisać można także w postaci macierzowej (11):

$$
(Y-X p)^{T}(Y-X p) \rightarrow \min
$$

przy czym: $\quad p_{i j} \geq 0, \sum_{j} p_{i j}=1$.

Podejście to było kontynuowane przez J.D. Kalbfleischa i J.F. Lawlessa (1984) oraz J.D. Kalbfleischa, J.F. Lawlessa i W.M. Vollmera (1983), a także w pracy 
M.T. Jonesa (2005). E. MacRae (1977) zauważa, iż wariancja błędu $u$ (9) zależy od wielkości $y_{t-1}$, a więc używając estymacji metodą najmniejszych kwadratów, otrzymamy zgodne, lecz nieefektywne oceny. W swojej pracy demonstruje ona także, jak można poprawić heteroskedastyczność oraz uzyskać bardziej efektywny estymator, używając uogólnionej wielokrotnej (iteracyjnej) techniki najmniejszych kwadratów dla skonstruowania macierzy prawdopodobieństw przejść. Pierwszym krokiem $\mathrm{w}$ tej procedurze jest oszacowanie macierzy przejść, a następnie - z jej użyciem - kalkulacja zgodnego estymatora macierzy warunkowej kowariancji, oznaczanej przez $\Omega$. Oszacowana macierz kowariancji jest wówczas użyta w celu uzyskania kolejnego oszacowania macierzy prawdopodobieństw, a cała procedura jest powtarzana aż do uzyskania konwergencji.

\subsection{Indeksy mobilności bazujące na macierzy przejść}

W przypadku macierzy prawdopodobieństw przejść oszacowanych procedurą Markowa, reprezentującą przepływy zatrudnienia i zmiany w poziomach płac w strukturze sektorowej na przestrzeni lat w danym kraju, sam proces mobilności rozumiany jest jako wszelkie odstępstwo od macierzy, w której obserwujemy jedynki na głównej przekątnej. W przypadku idealnej mobilności sytuacja nie jest już tak łatwa do określenia, gdyż sam układ elementów macierzy może w specyficznych warunkach doprowadzić do błędnych wniosków (Bartholomew, 1996).

W pracy wykorzystano dwa wskaźniki mobilności bazujące na oszacowanej (zgodnie z procedurą dla danych zagregowanych) macierzy prawdopodobieństw przejść. Pierwszym z nich jest wskaźnik MET (ang. mean exit time). Skrócona nazwa wskaźnika MET (12) sformułowana została przez A. Shorrocksa (1978), ponieważ S.J. Prais (1955) wykazał, iż przeciętny czas opuszczenia/pozostania w swojej kategorii można zapisać jako: $1 /\left(1-p_{i i}\right)$. Dla wszystkich $P$ z maksymalną przekątną wskaźnik ten jest bowiem odwrotnością średniej harmonicznej z przeciętnych czasów opuszczenia swojej kategorii, normalizowanej przez $\frac{m}{m-1}$.

Wskaźnik spełnia warunek normalizacji stawiany wskaźnikom mobilności - osiąga wartość 1 dla idealnej mobilności, gdy wszystkie prawdopodobieństwa przejść są takie same, $\forall P p_{i j}=\frac{1}{q} \forall i, j$. Nie spełnia on jednak warunku monotoniczności. Dodatkowo należy podkreślić, iż oceny wskaźnika MET są asymptotycznie 
normalne ${ }^{2}$, co umożliwia dość proste testowanie równości średnich wskaźników mobilności płac i zatrudnienia zbadanych z użyciem tego wskaźnika, a także badanie istotności wskaźnika korelacji między nimi:

$$
M E T=\frac{m-\sum_{i=1}^{m} p_{i}}{m-1} .
$$

Dla uzupełnienia, wykorzystano również ujęcie wskaźnika, które jest najczęściej stosowanym indeksem we wszelkich tego typu badaniach mobilności, przedstawione w pracy D.J. Bartholomew (1982) - wskaźnik IB (13). Wskaźnik ten nie spełnia warunku normalizacji. Bazuje on wyłącznie na informacji pochodzącej z głównej przekątnej macierzy przejść. Dla kwantylowych macierzy przejść, gdzie wagi $\pi_{i}$ w liczniku wskaźnika są jednakowe dla każdej klasy (z $m$ klas), możliwa jest normalizacja tego wskaźnika. Z oczywistych względów nie może ona być jednak stosowana dla macierzy sektorowych.

$$
I B=\frac{m-m \sum_{i=1}^{m} \pi_{i} p_{i i}}{m-1} .
$$

Wskaźnik (13), który zaproponował Bartholomew, mierzy przeciętne prawdopodobieństwo między wszystkimi kategoriami (sektorami) opuszczenia początkowej klasy w kolejnym okresie; jest również interpretowany jako znormalizowany dystans macierzy $P$ od macierzy jednostkowej (Bartholomew, 1996).

\section{Analiza empiryczna}

Analiza empiryczna przeprowadzona została w kilku etapach. W pierwszym z nich dokonano estymacji macierzy prawdopodobieństw przejść dla każdego z krajów OECD, oddzielnie dla łańcucha sektorowych płac oraz zatrudnienia. Tak otrzy-

${ }^{2}$ Schluter (1998) wykazał, iż $M E T \rightarrow N\left(\frac{q-\sum_{i=1}^{q} p_{i i}}{q-1}, \frac{1}{(q-1)^{2}} \sum_{i=1}^{q} p_{i}\left(1-p_{i}\right) / n_{i}\right)$, gdzie $q$ oznacza liczbę klas definiujących macierz przejść, $p_{i i}$ jest prawdopodobieństwem pozostania w klasie $i$ w okresie $t+1$ pod warunkiem przebywania w klasie $i$ w okresie $t$, natomiast $n_{i}$ jest całkowitą liczbą obserwacji w każdym wierszu $i$. 
mane macierze zostały następnie poddane procesowi obliczeniowemu indeksu mobilności. Ostatecznie uzyskano więc dwa zestawy wskaźników ruchliwości sektorowej płac oraz zatrudnienia.

W celu oszacowania modelu regresji, uwzględniającego szereg czynników wpływających pośrednio na oba typy mobilności (a zarazem łączącego oba zjawiska), dokonano wstępnej oceny statystycznej istotności autokorelacji przestrzennej. Dopiero w ostatnim etapie podjęto się obliczeń związanych z estymacją współczynników modelu przestrzennego i wyboru najbardziej odpowiedniej formy modelu.

Aby dokonać analizy mobilności na podstawie indeksów bazujących na oszacowanej macierzy przejść, należy zachować pełną spójność czasową i przestrzenną dostępnych danych statystycznych. Analiza z wykorzystaniem procesów Markowa ma również swoje wymogi. W związku z tym została ona przeprowadzona na podstawie klasyfikacji ISIC Rev. 3 dla krajów, których dane dla płac i zatrudnienia dostępne są w liczbie lat przewyższającej liczbę dostępnych sektorów klasyfikacji. Ostatecznie, aby uniknąć nieporównywalności wyników, zredukowane do tego samego wymiaru czasowego i klasyfikacyjnego dostępne dane statystyczne na chwilę przeprowadzenia obliczeń uzyskano dla 19 krajów z grupy OECD. Okres analizy obejmuje lata 1994-2010. Dane makroekonomiczne wybranych do analiz efektywności krajów OECD pochodzą z bazy danych statystycznych OECD. Stat Extracts.

Ze względu na konieczność wyboru krajów o pełnym pokryciu danych sektorowych w łańcuchu lat (bez przerw, luk, interpolacji poziomów sektorowych płac czy też zatrudnienia), które nie zawsze są sąsiadami, zaistniała konieczność skonstruowania macierzy wag przestrzennych, bazujących na dystansach ekonomicznych (Pietrzak, 2010). Jako dystans ten wybrano GDP ze środka łańcucha (rok 2000). Tego rodzaju techniczne posunięcie umożliwia ponadto dodatkową, zagnieżdżoną w modelu możliwość interpretacji współczynników konstruowanego modelu przestrzennego.

Wyniki obliczeń obu indeksów mobilności wraz ze statystykami przestrzennymi I Morana przedstawiono w tabeli 1. Wykrycie dość istotnych współczynników autokorelacji przestrzennej składnia do skonstruowania w kolejnym etapie modeli regresji przestrzennej (Rogerson, 2001; Kossowski, 2010).

Na podstawie uzyskanych $w$ analizie procesów Markowa dla danych zagregowanych wskaźników mobilności międzysektorowej płac oraz zatrudnienia rozpoczęto następnie konstrukcję trzech rodzajów modeli przestrzennej regresji, opartej na macierzach sąsiedztwa bazujących na odległościach ekonomicznych. Jak widać w tabeli 1, indeks $I B$ jest nienormowany, ma również nieco inne właściwości niż indeks MET Praisa-Shorrocksa. Procedura ta przeprowadzona została wobec tego dwukrotnie - osobno dla każdego z obu wybranych indeksów mobilności $(I B, M E T)$. Dzięki unormowanej mierze MET możliwa była jednak pełniejsza po- 
stać funkcyjna uzyskanego modelu regresji (większa liczba istotnych statystycznie zmiennych niezależnych).

Tabela 1. Wyniki pomiaru mobilności międzysektorowej wraz ze wskaźnikami autokorelacji przestrzennej Morana

\begin{tabular}{|c|c|c|c|c|}
\hline I Morana & $\begin{array}{c}-0,162186 \\
(0,041)\end{array}$ & $\begin{array}{c}-0,240371 \\
(0,022)\end{array}$ & $\begin{array}{c}-0,135365 \\
(0,051)\end{array}$ & $\begin{array}{c}-0,123471 \\
(0,061)\end{array}$ \\
\hline Kraj/Miara mobilności & $I B$ - place & $I B$ - zasoby & $M E T$ - płace & $M E T$ - zasoby \\
\hline Australia & 1,807289 & 1,994425 & 0,4910095 & 0,5461813 \\
\hline Czechy & 2,508789 & 2,465668 & 0,5083801 & 0,6138929 \\
\hline Dania & 2,899901 & 2,363432 & 0,8335388 & 0,5462833 \\
\hline Estonia & 2,941805 & 3,410794 & 0,7723064 & 0,7278849 \\
\hline Finlandia & 3,830733 & 2,105989 & 0,8723149 & 0,5213547 \\
\hline Holandia & 2,49602 & 3,082168 & 0,5501351 & 0,6605614 \\
\hline Izrael & 3,204624 & 2,606491 & 0,6647038 & 0,629388 \\
\hline Kanada & 2,367407 & 1,85974 & 0,64864 & 0,5008542 \\
\hline Korea & 3,08363 & 1,619477 & 0,7725917 & 0,5334339 \\
\hline Meksyk & 3,417346 & 3,885035 & 0,8503974 & 0,7890812 \\
\hline Norwegia & 1,99534 & 2,2705 & 0,4757108 & 0,6013053 \\
\hline Nowa Zelandia & 3,915214 & 1,950684 & 0,7725282 & 0,5967498 \\
\hline Polska & 2,088994 & 2,501459 & 0,5440655 & 0,521221 \\
\hline Portugalia & 3,009851 & 2,539712 & 0,8053321 & 0,5812409 \\
\hline Słowacja & 2,163305 & 2,552895 & 0,5590816 & 0,5811287 \\
\hline Słowenia & 2,001132 & 2,327522 & 0,5451828 & 0,7678331 \\
\hline Szwecja & 3,403235 & 1,515358 & 0,8992227 & 0,4577392 \\
\hline Węgry & 2,512324 & 1,908873 & 0,7468845 & 0,545411 \\
\hline Wielka Brytania & 1,876699 & 1,884263 & 0,3818557 & 0,6013064 \\
\hline
\end{tabular}

Źródło: obliczenia własne w autorskiej aplikacji komputerowej ${ }^{3}$

W tabeli 2 zawarte są wyniki estymacji modeli regresji liniowej $L M$ oraz modeli regresji opartej na macierzy wag przestrzennych: SEM (ang. spatial error model) oraz SLM (ang. spatial lagged model, inaczej $S A R$ ).

${ }^{3}$ Indeksy mobilności i same macierze przejść estymowano w specjalnie skonstruowanym na potrzeby analiz prowadzonych w niniejszej pracy oprogramowaniu o nazwie Markov, napisanym w języku C\#Sharp, przetłumaczonym w uprzednio przygotowanym skrypcie napisanym w języku Fortran. 
Tabela 2. Estymacja modeli regresji przestrzennej dla międzysektorowej mobilności zatrudnienia

\begin{tabular}{|c|c|c|c|c|c|c|}
\hline $\begin{array}{c}\text { Zmienna } \\
\text { zależna }\end{array}$ & $\begin{array}{r}\text { Międzys } \\
\text { zat }\end{array}$ & $\begin{array}{l}\text { ektorowa m } \\
\text { rudnienia (I }\end{array}$ & $\begin{array}{l}\text { obilność } \\
\text { B) }\end{array}$ & $\begin{array}{r}\text { Międzys } \\
\text { zatr }\end{array}$ & $\begin{array}{l}\text { sektorowa } \mathrm{m} \\
\text { udnienia }(M\end{array}$ & $\begin{array}{l}\text { obilność } \\
E E T)\end{array}$ \\
\hline Model & $L M$ & SEM & $S L M$ & $L M$ & SEM & SLM \\
\hline Stała & $\begin{array}{r}1,6888 \\
(0,0038)\end{array}$ & $\begin{array}{r}1,8807 \\
(0,0000)\end{array}$ & $\begin{array}{r}3,4384 \\
(0,0001)\end{array}$ & $\begin{array}{r}0,8649 \\
(0,0000)\end{array}$ & $\begin{array}{r}0,8739 \\
(0,0000)\end{array}$ & $\begin{array}{r}1,1139 \\
(0,0000)\end{array}$ \\
\hline $\begin{array}{l}\text { Międzysekto- } \\
\text { rowa mobil- } \\
\text { ność płac }(I B)\end{array}$ & $\begin{array}{r}0,4099 \\
(0,0216)\end{array}$ & $\begin{array}{r}0,350564 \\
(0,0074)\end{array}$ & $\begin{array}{r}0,3382 \\
(0,0093)\end{array}$ & & & \\
\hline $\begin{array}{l}\text { Międzysek- } \\
\text { torowa mo- } \\
\text { bilność płac } \\
(M E T)\end{array}$ & & & & $\begin{array}{r}0,3600 \\
(0,0042)\end{array}$ & $\begin{array}{r}0,3463 \\
(0,0000)\end{array}$ & $\begin{array}{r}0,3371 \\
(0,0000)\end{array}$ \\
\hline $\begin{array}{l}\text { Płace prze- } \\
\text { ciętne }\end{array}$ & $\begin{array}{r}-2,105 \mathrm{e}-05 \\
(0,0272)\end{array}$ & $\begin{array}{r}-2,156 \mathrm{e}-05 \\
(0,0001)\end{array}$ & $\begin{array}{r}-2.436 \mathrm{e}-05 \\
(0,0005)\end{array}$ & $\begin{array}{r}-6,272 \mathrm{e}-06 \\
(0,0041)\end{array}$ & $\begin{array}{r}-6,262 \mathrm{e}-06 \\
(0,0000)\end{array}$ & $\begin{array}{r}-6,851 \mathrm{e}-06 \\
(0,0000)\end{array}$ \\
\hline $\begin{array}{l}\text { Stopień } \\
\text { uzwiązkowie- } \\
\text { nia }\end{array}$ & & & & $\begin{array}{l}-0,0035 \\
(0,0051)\end{array}$ & $\begin{array}{l}-0,0035 \\
(0,0000)\end{array}$ & $\begin{array}{l}-0,0034 \\
(0,0000)\end{array}$ \\
\hline $\begin{array}{l}\text { Nierówności } \\
\text { płacowe (Gini) }\end{array}$ & & & & $\begin{array}{l}-1,2462 \\
(0,0639)\end{array}$ & $\begin{array}{l}-1.3257 \\
(0,0070)\end{array}$ & $\begin{array}{l}-1,3190 \\
(0,0080)\end{array}$ \\
\hline $\begin{array}{l}\text { Stopa bezro- } \\
\text { bocia }\end{array}$ & & & & $\begin{array}{r}-0,0242 \\
(0,0695)\end{array}$ & $\begin{array}{l}-0,9456 \\
(0,0015)\end{array}$ & $\begin{array}{l}-0,0241 \\
(0,0140)\end{array}$ \\
\hline$\lambda / W$ & & $\begin{array}{r}-0,9524 \\
(0,0012)\end{array}$ & $\begin{array}{r}-0,6469 \\
(0,0385) \\
\end{array}$ & & $\begin{array}{l}-0,9456 \\
(0,0015)\end{array}$ & $\begin{array}{r}-0,3805 \\
(0,1692) \\
\end{array}$ \\
\hline$R^{2}$ & 0,4464 & 0,6328 & 0,5924 & 0,7516 & 0,8064 & 0,7752 \\
\hline $\begin{array}{l}\text { Logarytm } \\
\text { funkcji wiary- } \\
\text { godności }\end{array}$ & $-17,1226$ & $-14,0783$ & $-14,5284$ & 22,8788 & 24,3298 & 23,7153 \\
\hline
\end{tabular}

Źródło: obliczenia własne w programach GeoDa oraz R

W modelu $S L M$ wprowadza się dodatkową zmienną niezależną $W$, będącą tzw. spatial lag, czyli średnią ważoną (według przyjętej macierzy wag przestrzennych) z wartości zmiennej zależnej występujących w obszarach sąsiedzkich (Suchecki, 2010). Uwzględnienie zależności przestrzennej dotyczącej błędu losowego umożliwia natomiast model błędu przestrzennego SEM (Rogerson, 2001; Kopczewska, 2010). Współczynnik $\lambda$ jest miarą siły wzajemnego skorelowania reszt z regresji klasycznego modelu liniowego i na jego podstawie można wnioskować o istnieniu istotnych czynników wpływających na zmienność zmiennej zależnej, które jednak nie zostały ujęte w modelu regresji - niemierzalnych, przypadkowych itp. (Kopczewska, 2010; Kossowski, 2010; Suchecki, 2010).

Uzyskane wyniki estymacji modeli regresji przestrzennej (przedstawione w tabeli 2) posiadają poprawne własności statystyczne (testy LR, BP, istotność 
współczynników, kryterium Akaike, $R^{2}$ ) oraz poprawną interpretację ekonomiczną (zarówno dla mobilności międzysektorowych płac, jak i pozostałych determinant rynku pracy). Jednak procedurę weryfikacji statystycznej istotności współczynników regresji i dopasowania do danych empirycznych najlepiej przeszły w obu przypadkach zmiennych zależnych $I B$ oraz MET modele $S E M$. Wykorzystanie macierzy sąsiedztwa, opartej na odległości ekonomicznej, zapewniło bardzo dobre dopasowanie modelu do danych empirycznych, co widoczne jest w wartościach logarytmu funkcji wiarygodności oraz wartościach współczynnika determinacji. Takie dopasowanie do danych empirycznych wynika głównie z pełniejszego opisu autozależności przestrzennych międzysektorowych mobilności zatrudnienia.

Analizując czynniki kształtujące poziom międzysektorowej mobilności zatrudnienia, należy zauważyć, iż zarówno w przypadku wskaźnika $M E T$, jak i $I B$ wysoce statystycznie istotna okazała się międzysektorowa mobilność płacowa, także w modelach przestrzennych. Oznacza to, iż wzrostowi natężenia ruchliwości struktury sektorowych płac towarzyszy wzmożony przepływ siły roboczej między sektorami. Co więcej, siła tego związku jest podobna przy uwzględnieniu czynnika przestrzennego. Również płaca przeciętna wykazuje związek z ruchliwością struktur zatrudnienia, jednak tutaj, zgodnie z oczekiwaniami, jest to oddziaływanie negatywne. W pełniejszej formie funkcyjnego modelu przestrzennego $S E M$, przy zastosowaniu wskaźnika MET, swoje oddziaływanie na przepływy międzysektorowe zatrudnienia wykazały także pozostałe determinanty, jak stopień uzwiązkowienia, nierówności płacowe (wskaźnik Giniego) oraz stopa bezrobocia (ujemna zależność). Istotna statystycznie wartość współczynnika autokorelacji przestrzennej $\lambda$ dowodzi natomiast występowania przestrzennie autoskorelowanych pozamodelowych czynników kształtujących międzysektorową mobilność zatrudnienia. Wybór takiej formy modelu (SEM) spowodował ponadto znaczną poprawę eksplanacyjności analizy.

\section{Podsumowanie}

W artykule przedstawiono zagadnienie wykorzystania przestrzennej macierzy wag, opartej na odległości ekonomicznej, w ramach prowadzonych przez autora analiz sprzęgających zjawiska sektorowych mobilności płac oraz zatrudnienia. Poszczególne wartości tak konstruowanej macierzy wyrażają potencjalne interakcje przestrzenne między badanymi obszarami. Wykorzystanie odległości ekonomicznej do budowy przestrzennej macierzy wag stanowi alternatywę określania siły oddziaływania dla ekonomicznych procesów przestrzennych, wobec odległości opartej na charakterystykach fizycznych badanych obszarów.

W ramach analizy przeprowadzono procedurę estymacji macierzy prawdopodobieństw przejść między sektorami zarówno dla płac, jak i zatrudnienia w wybra- 
nej grupie krajów OECD w latach 1994-2010. Na ich podstawie dokonano kalkulacji dwóch typów wskaźników mobilności płac oraz zatrudnienia. Tak otrzymane wskaźniki włączono następnie do konstrukcji klasycznych modeli regresji liniowej i przestrzennych, z wykorzystaniem macierzy wag bazującej na odległościach ekonomicznych (GDP). W obu przypadkach wskaźników mobilności modele wykorzystujące macierze oparte na odległościach ekonomicznych wykazały największą precyzję i poprawność wyników (zwłaszcza model SEM). Przeprowadzone modelowanie wskazuje, iż w analizie mobilności zatrudnienia nawet na najbardziej zagregowanym poziomie obserwacji, jakim jest struktura sektorowa, warto uwzględnić założenie o występowaniu pewnych przestrzennie zależnych zmiennych ukrytych i niemierzalnych, w istotny sposób kształtujących jej natężenie. Oznacza to, że wykorzystanie w modelach ekonometrycznych poziomu ruchliwości zatrudnienia (nawet na poziomie międzysektorowym) macierzy wag opartych na odległości ekonomicznej znacznie zwiększa poprawność interpretacyjną oddziaływania zmiennych objaśniających, a co za tym idzie - znacznie poprawia jakość prowadzonych badań.

\section{Bibliografia}

Abraham K.G., Katz L.F. (1986), Cyclical unemployment: Sectoral shifts or aggregate disturbances?, „Journal of Political Economy”, vol. 94, no. 3, s. 507-522.

Aghion P., Blanchard O. (1994), Growth, inequality and globalization: theory, history and policy, Cambridge University Press, Cambridge.

Altonji J.G., Ham J.C. (1990), Variation in Employment Growth in Canada: The Role of External, National, Regional, and Industrial Factors, „Journal of Labor Economics”, vol. 8, no. 1, s. $198-236$.

Anderson T.W., Goodman L.A. (1957), Statistical inference about Markov chains, „Annals of Mathematical Statistics", vol. 28, no. 1, s. 89-110.

Antel J.J. (1983), Job change of young men, Ph.D. Dissertation, University of California, Los Angeles.

Antel J.J. (1986), Human Capital Investment Specialization and the Wage Effects of Voluntary Labor Mobility, „Review of Economics and Statistics”, vol. 68, no. 3, s. 477-483.

Bartel A., Borjas G. (1981), Wage growth and job turnover: An empirical analysis, „Studies in Labor Markets", vol. 1, s. 65-90.

Bartholomew D.J. (1982), Stochastic models for social processes, Wiley, New York.

Bartholomew D.J. (1996), The statistical approach to social measurement, Academic Press, New York.

Basile R. (2010), Intra-distribution dynamics of regional per-capita income in Europe: evidence from alternative conditional density estimators, „Statistica”, vol. 70, no. 1, s. 3-22.

Becker G.S. (1962), Investment in human capital: A theoretical analysis, „Journal of Political Economy", vol. 70, no. 5, s. 9-49.

Bigsten A., Mengistae T., Shimeles A. (2007), Mobility and earnings in Ethiopia's urban labor markets 1994-2004, „Policy Research Working Paper Series”, The World Bank 4168, The World Bank. 
Blumen I.M., Kogan M., McCarthy P.J. (1955), The Industrial Mobility of Labor as a Probability Process, Cornell University Press, Ithaca.

Bosch M., Maloney W.F. (2010), Comparative analysis of labor market dynamics using Markov processes: An application to informality, „Labour Economics”, vol. 17, no. 4, s. 621-631.

Brainard S., Cutler D. (1993), Sectoral Shifts and Cyclical Unemployment Reconsidered, „Quarterly Journal of Economics", vol. 108, s. 219-244.

Burdett K., (1978), A theory of employee job search and quit rates, „The American Economic Review", vol. 68 , no. 1, s. 212-220.

Canavire-Bacarreza G.J., Soria L.F. (2007), Unemployment Duration and Labor Mobility in Argentina: A Socioeconomic-Based Pre- and Post-Crisis Analysis, „CEDLAS, Working Papers”, Universidad Nacional de La Plata 0054.

Cardoso A.R. (2006), Wage mobility: Do institutions make a difference?, „Labour Economics”, vol. 13 , s. 387-404.

Chan W. (1996), Intersectoral Mobility and Short-Run Labor Market Adjustments, „Journal of Labor Economics", vol. 14, no. 3, s. 454-471.

Fabrizi E., Mussida C., (2009), The Determinants of Labour Market Transitions, „Giornale degli Economisti e Annali di Economia", vol. 68, no. 2, s. 233-265.

Friedman M. (1962), Capitalism and Freedom: The Relation Between Economic Freedom and Political Freedom, „Capitalism and Freedom”, s. 7-17.

Funkhouser E. (1996), The urban informal sector in Central America: Household survey evidence, „World Development”, vol. 24, no. 11, s. 1737-1751.

Funkhouser E. (1997), Mobility and Labor Market Segmentation: The Urban Labor Market in El Salvador, „Economic Development and Cultural Change”, vol. 46, no. 1, s. 123-153.

Garonna P. (2000), Intersectoral labour reallocations and unemployment in Italy, „Labour Economics", vol. 7, no. 6, s. 711-728.

Jones M.T. (2005), Estimating Markov transition matrices using proportions data: an application to credit risk, „IMF Working Paper”, no. 219.

Jovanovic B. (1979), Firm-specific Capital and Turnover, „Journal of Political Economy”, vol. 87, no. 6 , s. $1246-1260$.

Kalbfleisch J.D., Lawless J.F. (1984), Least-squares estimation of transition probabilities from aggregate data, „Canadian Journal of Statistics”, vol. 12, no. 3, s. 169-82.

Kalbfleisch J.D., Lawless J.F., Vollmer W.M. (1983), Estimation in Markov models from aggregate data, „Biometrics”, vol. 39, s. 907-919.

Keith K., McWilliams A. (1997), Job Mobility and Gender-Based Wage Growth Differentials, „Economic Inquiry", vol. 35, no. 2, s. 320-333.

Keith K., McWilliams A. (1999), The returns to mobility and job search by gender, „ILR Review”, vol. 52 , no. 3 , s. $460-477$.

Kopczewska K. (2006), Ekonometria i statystyka przestrzenna, CeDeWu, Warszawa.

Kopczewska K. (2010), Modele zmian stopy bezrobocia w ujęciu przestrzennym, „Wiadomości Statystyczne", vol. 5, s. 26-40.

Kopczuk W.E.S. (2010), Earnings inequality and mobility in the United States: evidence from social security data since 1937, „Quarterly Journal of Economics”, vol. 125, s. 91-128.

Kossowski T. (2010), Teoretyczne aspekty modelowania przestrzennego w badaniach regionalnych, „Biuletyn Instytutu Geografii Społeczno-Ekonomicznej i Gospodarki Przestrzennej Uniwersytetu im. Adama Mickiewicza", vol. 12, s. 9-26.

Krstic G., Sanfey P. (2007), Mobility, poverty and well-being among the informally employed in Bosnia and Herzegovina, „Working Papers 101”, European Bank for Reconstruction and Development, Office of the Chief Economist.

Krugman P. (1994), Europe Jobless, America Penniless?, „Foreign Policy”, vol. 95, s. 19-34. 
Lee T.C., Judge G.G., Zellner A. (1970), Estimating the parameters of the Markov probability model from aggregate time series data, North-Holland Pub. Co., Amsterdam.

Light A., McGarry K. (1998), Job change patterns and the wages of young men, „Review of Economics and Statistics", vol. 80, no. 2, s. 276-286.

Lilien D.M. (1982), Sectoral Shifts and Cyclical Unemployment, „Journal of Political Economy”, vol. 90, s. 777-793.

Loprest P.J. (1992), Gender differences in wage growth and job mobility, „American Economic Review", vol. 82, s. 526-532.

Loungani P., Rogerson R. (1989), Cyclical Fluctuations and Sectoral Reallocation: Evidence from the PSID, ,Journal of Monetary Economics”, vol. 23, no. 2, s. 259-273.

MacRae E. (1977), Estimation of time-varying Markov processes with aggregate data, „Econometrica", vol. 45, s. 183-198.

Maloney W.F. (1999), Does informality imply segmentation in urban labor markets? Evidence from sectoral transitions in Mexico, „The World Bank Economic Review”, vol. 13, no. 2, s. 275-302.

Markov A.A. (1906), Rasprostranenie zakona bol'shih chisel na velichiny, zavisyaschie drug ot druga, „Izvestiya Fiziko-matematicheskogo obschestva pri Kazanskom universitete”, vol. 2, no. 15 , s. $135-156$.

McLaughlin K.J. (1990), General Productivity Growth in a Theory of Quits and Layoffs, „Journal of Labor Economics", vol. 8, no. 1, s. 75-98.

Mincer J. (1986), Wage changes in job changes, „NBER Working Paper”, no. 1907.

Moffitt R.A., Gottschalk P. (2002), Trends in the transitory variance of earnings in the United States, „Economic Journal”, vol. 112, no. 478, s. 68-73.

Moore M.J., Viscusi W., Zeckhauser R.J. (1998), The Anatomy of Jumps and Falls in Wages, „Research in Labor Economics", vol. 17, s. 201-232.

Murphy K.M. (1990), Empirical Age - Earnings Profiles, „Journal of Labor Economics”, vol. 8, s. $202-229$.

Murphy K.M., Topel R.H. (1987), The evolution of unemployment in the United States: 1968-1985, „NBER Macroeconomics Annual”, vol. 2, s. 11-58.

Mussida C., Muhammad R.A., Pastore F. (2014), Note on Lilien and modified Lilien index, „The Stata Journal", vol. 4, s. 398-406.

Mussida C., Pastore F. (2012), Is There a Southern-Sclerosis? Worker Reallocation and Regional Unemployment in Italy, „IZA Discussion Papers 6954”, Institute for the Study of Labor.

Naticchioni P., Panigo D. (2004), Employment protection, job-tenure and short term mobility wage gains - A new explanation for the Italian case, „Working Papers - Dipartimento di Economia 4-DEISFOL", Dipartimento di Economia, Sapienza University of Rome.

Neal D. (1995), Industry - specific human capital; evidence from displaced workers, „Journal of Labor Economics", vol. 13, s. 653-677.

Palley T. I. (1992), Sectoral Shifts and Cyclical Unemployment: A Reconsideration, „Economic Inquiry", vol. 30, s. 117-133.

Pietrzak M.B. (2010), Wykorzystanie odległości ekonomicznej w przestrzennej analizie stopy bezrobocia dla Polski, „Oeconomia Copernicana”, vol. 1, s. 79-98.

Prais S.J. (1955), Measuring Social Mobility, „Journal of the Royal Statistical Society”, vol. 118, s. $56-66$.

Rogerson P. (2001), Statistical methods for geography, SAGE Publications, London-Thousand Oaks-New Delhi.

Schluter C. (1998), Statistical inference with mobility indices, „Economics Letters”, vol. 59, no. 2, s. $157-162$.

Shimer R., Alvarez F. (2009), Unemployment and human capital, „Meeting Papers 28”, Society for Economic Dynamics.

Shorrocks A. (1978), The Measurement of Mobility, „Econometrica”, vol. 46, s. 1013-1024. 
Suchecka J. (2014), Statystyka przestrzenna. Metody analiz struktur przestrzennych, Wydawnictwo C.H. Beck, Warszawa.

Suchecki B. (2010), Ekonometria przestrzenna. Metody i modele analizy danych przestrzennych, Wydawnictwo C.H. Beck, Warszawa.

Tansel A., Kan E.O. (2012), The formal/informal employment earnings gap: evidence from Turkey, „IZA Discussion Papers 6556”, Institute for the Study of Labor (IZA).

Topel R.H., Ward M.P. (1992), Job mobility and the careers of young men, „Quarterly Journal of Economics", vol. 107, s. 439-479.

Wacziarg R., Wallack J. S. (2004), Trade liberalization and intersectoral labor movements, „Journal of International Economics", vol. 64, s. 411-439.

Zelias A. (red.) (1991), Ekonometria przestrzenna, PWE, Warszawa.

\section{A spatial approach to intersectoral labor and wage mobility}

Abstract: The article presents the problem of the application of spatial weight matrix based on economic distance in spatial analysis of the intersectoral mobility of labor and wage. The spatial weight matrix expresses potential spatial interactions between the researched regions and forms a basis for further construction of spatial econometric model. Calculations of economic distance were based on the level of chosen measure of labor or wage mobility (respectively), whereas in the spatial model data of their chosen determinants were used (such as the level of unemployment, the average earnings, the level of institutionalism, the index of wage or income inequality). Wide time spectrum of the analysis was obtained thanks to the measure of mobility based on a transition probability matrix estimated with the use of the analysis of Markov processes for aggregated data. Because of the availability of homogeneous, highly aggregated sectoral data only for the period 1994-2010, the analyses were performed for 19 selected OECD countries.

Keywords: labor mobility, labour market, wage mobility, Markov chains, wage inequality, mobility.

JEL: J21, J62

\begin{tabular}{|l|l|}
\hline \multirow{2}{*}{ OPEN ACCESS } & $\begin{array}{l}\text { C by the author, licensee Łódź University - Łódź University Press, Łódź, Poland. } \\
\text { This article is an open access article distributed under the terms and conditions } \\
\text { of the Creative Commons Attribution license C(-BY } \\
\text { (http://creativecommons.org/licenses/by/3.0/) }\end{array}$ \\
\cline { 2 - 2 } & Received: 2016-08-31; verified: 2016-11-05. Accepted: 2016-11-08 \\
\hline
\end{tabular}

